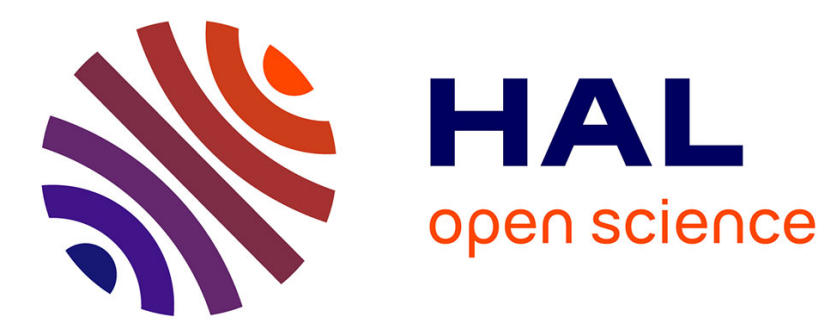

\title{
Human odontoblast cell numbers after dental injury
}

P E Murray, I About, P J Lumley, J.-C Franquin, M Remusat, A J Smith

\section{To cite this version:}

P E Murray, I About, P J Lumley, J.-C Franquin, M Remusat, et al.. Human odontoblast cell numbers after dental injury. Journal of Dentistry, 2000, 28 (4), pp.277-285. 10.1016/s0300-5712(99)00078-0 . hal-03552468

\section{HAL Id: hal-03552468 \\ https://hal.science/hal-03552468}

Submitted on 2 Feb 2022

HAL is a multi-disciplinary open access archive for the deposit and dissemination of scientific research documents, whether they are published or not. The documents may come from teaching and research institutions in France or abroad, or from public or private research centers.
L'archive ouverte pluridisciplinaire HAL, est destinée au dépôt et à la diffusion de documents scientifiques de niveau recherche, publiés ou non, émanant des établissements d'enseignement et de recherche français ou étrangers, des laboratoires publics ou privés. 


\title{
Human odontoblast cell numbers after dental injury
}

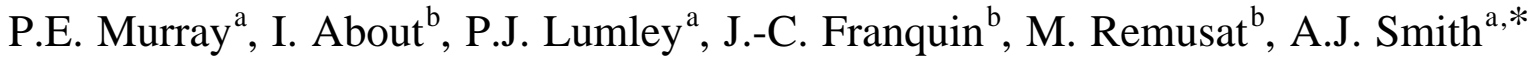 \\ ${ }^{a}$ Oral Biology, The School of Dentistry, The University of Birmingham, St. Chad's Queensway, Birmingham B4 6NN, UK \\ ${ }^{\mathrm{b}}$ Faculte d'Odontologie, Universite de la Mediteranee, Marseille, France
}

\begin{abstract}
Objectives: The purpose of this study was to measure the changes in odontoblast cell numbers in response to cavity restoration variables and patient factors, and the effect these factors have on dental repair by tertiary dentinogenesis. The number of vital odontoblasts is a critical factor for pulpal repair following restorative surgery, and yet little information is available on these cell numbers.

Methods: Class V non-exposed cavities were prepared in the buccal surface of intact first or second premolar teeth of 27 patients, between 9 and 17 years of age. Following tooth extraction (28-163 days) the area of reactionary dentine and the area of the odontoblasts were measured histomorphometrically.

Results: Patient factors, as well as cavity preparation and restoration variables, had little effect on the numbers of odontoblasts per pulpal unit area. However, the age of the patient did appear to have an effect on the reactionary dentine secretory capacity of odontoblasts per unit area, and on the relative number of odontoblasts beneath cut dentinal tubules.

Conclusions: Odontoblast cell numbers were maintained following the preparation of cavities cut into dentine with a $0.5 \mathrm{~mm}$ residual dentine thickness. The repair capacity of the pulp-dentine complex would appear to be age dependent, this may explain differences in the success of various restorative treatments between patient
\end{abstract}

Keywords: Tertiary dentinogenesis; Cavity restoration; Pulp; Odontoblast; Caries; Dentine thickness

\section{Introduction}

Tooth dentinogenesis is a dynamic process, regulated by a single layer of highly differentiated post-mitotic odontoblast cells. The intrinsic capacity of the dental pulp to repair lost or damaged dentine matrix, and to increase the barrier between itself and the injurious stimuli, is dependent on the vitality of the odontoblast cell layer, following caries, attrition, abrasion, erosion, tissue damage, and trauma [1-5]. Not only must the odontoblasts survive these challenges, but they must also detect and respond to them by synthesising and secreting a reactionary dentine matrix to protect the tooth pulp from further injury. In many cases the most severe challenge to odontoblast survival is not a direct result of these environmental or accidental events, but from the surgical techniques and materials used to restore tooth structure following these events [6-12]. The successful resolutions of restorative treatments are dependent upon harnessing and utilising the natural repair responses of the pulpal cell populations, especially the odontoblasts. The other pulpal cell populations which occupy the sub-odontoblast layer and the pulp core, are important in supporting dentinogenesis, but do not play a direct role in the secretion of dentine matrix [13]. Dentine matrix can be classified as either primary, secondary or tertiary in origin according to the chronology and circumstances of its secretion by the odontoblasts $[14,15]$. Primary dentine is secreted at a rate of approximately $4 \mu \mathrm{m}$ per day during tooth development, until the completion of root formation [16]. Physiological secondary dentine is laid down after completion of root formation in increments of approximately $0.5 \mu \mathrm{m}$ per day throughout life $[17,18]$. Unlike primary or secondary dentine that forms along the entire pulp-dentine border, tertiary dentine is focally secreted by odontoblasts in response to primary and secondary dentine injury. The process of tertiary dentine secretion can further be classified as being reactionary or reparative in origin, depending on the severity of the initiating response, and the conditions under which the newly deposited dentine matrix was formed. If these cells survive cavity preparation and restoration surgery, they may secrete a reactionary dentine matrix of repair.

If these cells are irreversibly injured, they must be replaced by a second generation of newly differentiated 
odobtoblast-like cells, before the secretion of a reparative dentine matrix of repair can take place [19,20]. Reparative dentinogenesis is a much more complex process than reactionary dentinogenesis, and is generally observed following more severe injurious cavity preparation, or a pulp exposure situation. The minimisation of pulpal injury during cavity preparation is clinically advantageous, as it maintains pulp cell function and viability, and reduces the probability of post-operative pulp complications from occurring. The preservation of pulpal cell function and viability following dentine cavity preparation requires the potentially injurious effects of the cavity preparation and restoration procedures to be studied. The choice of different restoration materials and the variables of cavity cutting have often had a highly controversial effect on the dental pulp. For example, the increased traumatic operative procedures involved in cutting deeper cavities, have been claimed to be destructive to the underlying odontoblast cell population [21-23], whilst others dispute this, and claim that factors such as pulpal inflammation caused by microleakage is of greater importance for pulp viability [24]. Also controversial, is the application of zinc oxide eugenol (ZOE) and calcium hydroxide products to lined prepared cavities. The application of calcium hydroxide and ZOE products have been claimed to elicit a persistent stimulating effect on the pulp resulting in its eventual obliteration [25]. Others however, have claimed that the cavity restoration material has had little effect on odontoblast activity [10,26]. Furthermore, the process of tertiary or reactionary dentine formation is a continuing focus of interest, because there is no artificial material that can be placed into a tooth that provides better protection for the pulp than dentine [27]. But the process of pulpal repair appears complex and the mechanisms remain incompletely understood [28]. Hence, the purpose of this study was to examine odontoblast cell survival and reactionary dentine secretion, in response to cavity preparation and restoration factors, in the permanent first or second premolar teeth of patients aged between 9 and 17 years of age.

\section{Materials and methods}

Class V cavity preparations were placed in the buccal surface, $1 \mathrm{~mm}$ above the level of the cementoenamel junction, of intact first or second noncarious intact premolar teeth, scheduled for extraction for orthodontic reasons. Teeth were polished with pumice paste to remove plaque and calculus, prior to the operative procedure. The tooth surface was isolated with sterile cotton rolls, and saliva was controlled with high-speed evacuation. Cavities were cut into dentine with a Maillefer 129, ISO 010 bur using the least possible pressure at a drill speed of $4000 \mathrm{rpm}$ with water spray coolant.

The cavities were cut into the dentine to a range of cavity residual dentine thicknesses, with the floor of the prepared cavities being maintained curved and parallel to the outer surface of the tooth. The walls of the cavities were immediately conditioned with a $17 \%$ disodium ethylene diamine tetraacetate solution, $\mathrm{pH} 8$ (Roth International, Chicago, USA), for $15 \mathrm{~s}$, flushed with sterile water for $5 \mathrm{~s}$, and dried with an extremely light airstream for $2 \mathrm{~s}$. Teeth were randomly assigned to three experimental groups for cavity restoration. Amalgam (Contour, Kerr, Italy) was used to restore 17 cavities, in conjunction with a calcium hydroxide lining material (Dycal, Dentsply, Milford, DE, USA). A further 7 cavities were restored with Zinc-Oxide Eugenol (ZOE) (Kalzinol, Dentsply, Milford, DE, USA) as well as a further 3 cavity restorations with the Intermediate Restoration Material (IRM) (De Trey Dentsply, Zurich, Switzerland). All materials were prepared and used, strictly according to manufacturer's instructions. The teeth were extracted from 27 patients, aged between 9 and 17 years of age, after a post-operative interval of $28-163$ days. The patients had given their informed consent to the tooth extraction, at the Dental Hospital of Marseille, France. The teeth were extracted using a local anesthetic, the roots were clipped and the teeth were then fixed in $10 \%$ neutralbuffered formalin for $24 \mathrm{~h}$, demineralised in sodium formate acid $(3.4 \%$ sodium formate $[\mathrm{HCOONa}$ ] in $15 \%$ formic acid) for 21 days, and then routinely processed and embedded in paraffin wax for histological examination. Sections were cut at $6 \mu \mathrm{m}$ and routinely stained with hematoxylin and eosin. The area of reactionary dentine was estimated histomorphometrically at $10 \times$ magnification, using a grid eyepiece graticule [29].

In addition, the number of odontoblasts was counted histomorphometrically per $2112 \mu \mathrm{m}^{2}$ of pulpal unit area using a grid eyepiece graticule [29]. Odontoblasts were counted beneath the dentinal tubules cut by cavity preparation, and also on the opposite side of the pulp chamber, independent of the cavity preparation within each tooth section. The pulpal inflammatory responses were categorised as either slight, moderate or severe, according to the criteria detailed by Baume and Fiore-Donno [30]. The raw data from all the experiments were examined using linear regression analysis of variance (LRANOVA) tests, for raw data containing regressors (STATview software, Cherwell Inc, USA) and analysis of variance (ANOVA) tests for comparing the difference between means (SuperANOVA software, Cherwell Inc, USA). ANOVA post hoc tests [31] were used to compare the differences between variables. These methods have been claimed to be the most versatile and most conservative multiple comparison statistical tests [32]. The measured variables are shown in Table 1.

\section{Results}

\subsection{Histomorphology of reactionary dentine}

The preservation of the single layer of odontoblasts could be observed beneath the cavity restorations (Fig. 1). In some 
Table 1

Pathohistometric raw data from 27 patients

\begin{tabular}{|c|c|c|c|c|c|c|c|c|c|c|c|c|c|c|}
\hline $\begin{array}{l}\text { Age of } \\
\text { patient } \\
\text { (years) }\end{array}$ & $\begin{array}{l}\text { Time } \\
\text { elapsed } \\
\text { since } \\
\text { surgery } \\
\text { (days) }\end{array}$ & $\begin{array}{l}\text { Reactionary } \\
\text { dentine } \\
\text { area } \mathrm{mm}^{2} \text { ) }\end{array}$ & $\begin{array}{l}\text { Pulpal } \\
\text { inflammatory } \\
\text { activity } \\
(+++=\text { severe, } \\
++=\text { moderate } \\
+=\text { slight })\end{array}$ & $\begin{array}{l}\text { Cavity } \\
\text { restoration } \\
\text { product }\end{array}$ & $\begin{array}{l}\text { Patient } \\
\text { gender } \\
(\mathrm{F}=\text { female, } \\
\mathrm{M}=\text { male })\end{array}$ & $\begin{array}{l}\text { Tooth } \\
\text { position } \\
(\mathrm{Mx}=\text { maxillary, } \\
\mathrm{Md}=\text { mandibular })\end{array}$ & $\begin{array}{l}\text { Cavity } \\
\text { residual } \\
\text { dentine } \\
\text { thickness } \\
(\mathrm{mm})\end{array}$ & $\begin{array}{l}\text { Cavity } \\
\text { width } \\
(\mathrm{mm})\end{array}$ & $\begin{array}{l}\text { Cavity } \\
\text { depth } \\
(\mathrm{mm})\end{array}$ & $\begin{array}{l}\text { Cavity } \\
\text { volume } \\
\left(\mathrm{mm}^{3}\right)\end{array}$ & $\begin{array}{l}\text { Cavity } \\
\text { floor } \\
\text { surface } \\
\text { area } \\
\left(\mathrm{mm}^{2}\right)\end{array}$ & $\begin{array}{l}\text { Cavity } \\
\text { walls } \\
\text { surface } \\
\text { area }\left(\mathrm{mm}^{2}\right)\end{array}$ & $\begin{array}{l}\text { Odontoblast } \\
\text { numbers } \\
\text { beneath cut } \\
\text { dentinal } \\
\text { tubules }\end{array}$ & $\begin{array}{l}\text { Odontoblast } \\
\text { numbers } \\
\text { independent } \\
\text { of cut } \\
\text { dentinal } \\
\text { tubules }\end{array}$ \\
\hline 17 & 39 & 2.79 & $(++)$ & Dycal & $\mathrm{F}$ & $\mathrm{Md}$ & 0.63 & 2.27 & 1.1 & 2.32 & 4.48 & 11.89 & 19 & 13 \\
\hline 11 & 28 & 0.47 & $(++)$ & Dycal & M & Mx & 1.06 & 1.89 & 0.44 & 1.23 & 2.81 & 5.40 & 20 & 23 \\
\hline 14 & 28 & 0.95 & $(+)$ & Dycal & $\mathrm{M}$ & Mx & 0.88 & 1.51 & 0.25 & 1.80 & 1.80 & 3.00 & 12 & 18 \\
\hline 11 & 32 & 0.98 & $(++)$ & Dycal & M & $\mathrm{Mx}$ & 0.73 & 1.45 & 0.18 & 0.29 & 1.65 & 2.46 & 23 & 11 \\
\hline 17 & 35 & 0.74 & $(+)$ & Dycal & M & $\mathrm{Md}$ & 0.84 & 1.77 & 0.95 & 2.34 & 2.45 & 7.71 & 16 & 11 \\
\hline 11 & 33 & 0.33 & $(+)$ & Dycal & M & $\mathrm{Md}$ & 1.38 & 1.74 & 0.63 & 1.51 & 2.38 & 5.83 & 22 & 12 \\
\hline 11 & 33 & 0.00 & $(+)$ & Dycal & M & $\mathrm{Md}$ & 1.69 & 1.96 & 0.51 & 1.53 & 3.01 & 6.11 & 21 & 26 \\
\hline 14 & 57 & 1.58 & $(+)$ & Dycal & $\mathrm{F}$ & Mx & 1.10 & 1.87 & 0.51 & 1.39 & 2.74 & 5.70 & 17 & 14 \\
\hline 14 & 56 & 1.83 & $(+)$ & Dycal & $\mathrm{M}$ & Mx & 0.88 & 1.51 & 0.38 & 0.69 & 1.80 & 3.60 & 20 & 11 \\
\hline 9 & 150 & 0.47 & $(++)$ & Dycal & $\mathrm{F}$ & $\mathrm{Md}$ & 1.38 & 1.58 & 0.19 & 0.37 & 1.95 & 2.89 & 23 & 17 \\
\hline 10 & 85 & 1.50 & $(+)$ & Dycal & $\mathrm{M}$ & Mx & 1.13 & 1.96 & 0.47 & 1.41 & 3.01 & 5.88 & 15 & 16 \\
\hline 10 & 56 & 0.98 & $(+)$ & Dycal & $\mathrm{F}$ & Mx & 1.03 & 2.15 & 0.25 & 0.92 & 3.62 & 5.32 & 23 & 13 \\
\hline 14 & 74 & 0.00 & $(+)$ & Dycal & $\mathrm{F}$ & $\mathrm{Md}$ & 1.63 & 1.45 & 0.76 & 1.26 & 1.65 & 5.11 & 27 & 14 \\
\hline 11 & 163 & 0.00 & $(+)$ & Dycal & $\mathrm{M}$ & Mx & 1.00 & 1.77 & 0.69 & 1.71 & 2.45 & 6.30 & 15 & 18 \\
\hline 10 & 124 & 0.79 & $(+)$ & Dycal & $\mathrm{M}$ & $\mathrm{Mx}$ & 0.96 & 1.51 & 1.14 & 2.06 & 1.80 & 7.21 & 17 & 20 \\
\hline 11 & 84 & 0.54 & $(+)$ & Dycal & $\mathrm{F}$ & $\mathrm{Mx}$ & 0.77 & 1.39 & 0.48 & 0.73 & 1.51 & 3.61 & 20 & 11 \\
\hline 10 & 28 & 0.00 & $(++)$ & IRM & M & $\mathrm{Md}$ & 1.32 & 2.02 & 0.69 & 2.24 & 3.20 & 7.61 & 22 & 22 \\
\hline 12 & 77 & 1.27 & $(++)$ & IRM & $\mathrm{F}$ & Mx & 0.57 & 2.27 & 0.38 & 1.54 & 4.05 & 6.76 & 11 & 20 \\
\hline 12 & 28 & 0.23 & $(++)$ & IRM & $\mathrm{F}$ & $\mathrm{Md}$ & 1.60 & 1.26 & 0.13 & 0.16 & 1.25 & 1.75 & 26 & 17 \\
\hline 12 & 123 & 0.12 & $(++)$ & $\mathrm{ZOE}$ & M & $M x$ & 1.22 & 1.66 & 0.99 & 2.11 & 2.17 & 7.37 & 13 & 12 \\
\hline 10 & 127 & 0.16 & $(++)$ & $\mathrm{ZOE}$ & $\mathrm{F}$ & $\mathrm{Md}$ & 1.57 & 1.57 & 0.88 & 1.65 & 1.93 & 6.25 & 23 & 20 \\
\hline 10 & 90 & 0.03 & $(+)$ & $\mathrm{ZOE}$ & $\mathrm{F}$ & $\mathrm{Md}$ & 1.62 & 1.86 & 0.53 & 1.41 & 2.72 & 5.83 & 16 & 23 \\
\hline 16 & 61 & 0.00 & $(++)$ & $\mathrm{ZOE}$ & $\mathrm{F}$ & $M x$ & 1.45 & 1.69 & 0.44 & 0.96 & 2.24 & 4.56 & 20 & 20 \\
\hline 10 & 29 & 0.00 & $(+)$ & $\mathrm{ZOE}$ & $\mathrm{F}$ & $\mathrm{Mx}$ & 0.95 & 1.53 & 0.93 & 1.66 & 1.83 & 6.30 & 22 & 20 \\
\hline 10 & 28 & 0.00 & $(+)$ & $\mathrm{ZOE}$ & $\mathrm{F}$ & $\mathrm{Md}$ & 0.95 & 1.73 & 1.20 & 2.73 & 2.34 & 8.84 & 16 & 26 \\
\hline 10 & 28 & 0.00 & $(++)$ & $\mathrm{ZOE}$ & $\mathrm{M}$ & $\mathrm{Md}$ & 0.98 & 1.57 & 0.97 & 0.00 & 1.83 & 6.71 & 22 & 24 \\
\hline 10 & 154 & 0.35 & $(+++)$ & Dycal & $\mathrm{F}$ & $\mathrm{Md}$ & 0.78 & 1.62 & 1.48 & 1.62 & 2.06 & 9.58 & 22 & 24 \\
\hline
\end{tabular}




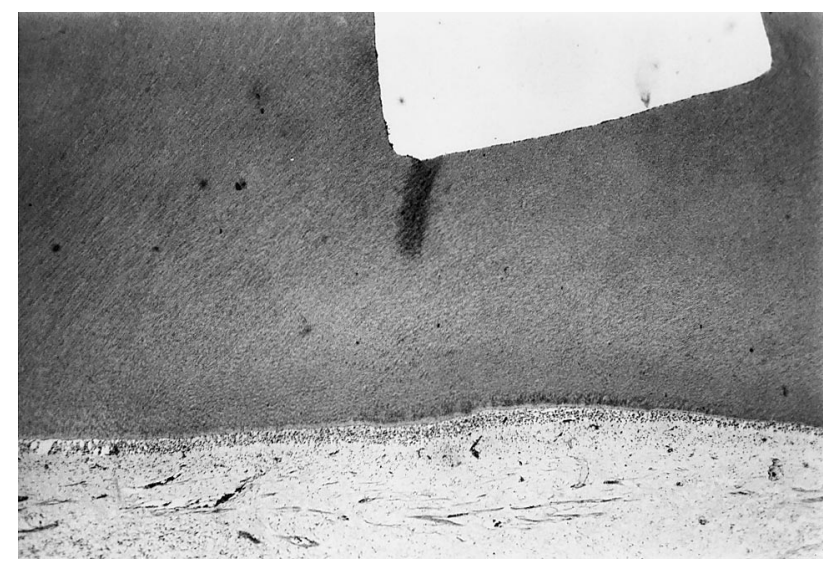

Fig. 1. Preservation of the pulp tissue following cavity restoration: 14 yearold female patient with an amalgam/Dycal restored cavity (magnification $320 \times)$ - 74 days had elapsed between cavity restoration and tooth extraction.

cases, a histomorphological evaluation of the extracted premolar specimens revealed the presence of a tertiary dentine matrix beneath dentinal tubules cut by cavity preparation. The tertiary dentine matrix appeared to have a tubular continuity between the secondary dentine matrix and the pre-existing odontoblasts (Fig. 2). These observations were necessary to classify the secreted dentine matrix as being reactionary in origin [33].

\subsection{Controls}

The RDT of all the cavity restorations was examined within each of the test groups to remove the possible influence of differences in the residual dentine thickness of the cavity preparations. No statistical differences $p=0.05$ were observed for: age of the patient at treatment (ANOVA $p=0.661$ ); cavity restoration material (ANOVA $p=0.519$ ); pulpal inflammatory activity (ANOVA $p=0.513$ ); gender of patient (ANOVA

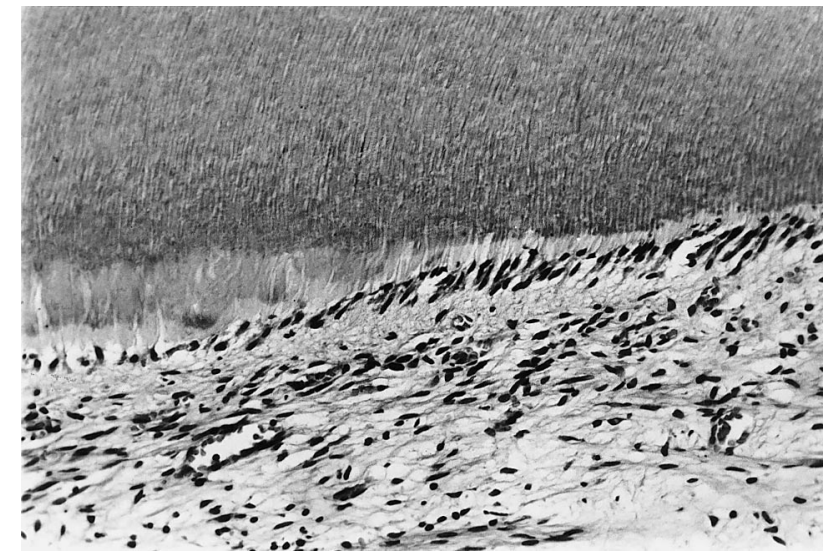

Fig. 2. Odontoblast cells associated with areas of reactionary dentinogenesis and adjacent areas of dentine. 14 year-old female patient with an amalgam/Dycal restored cavity (magnification $320 \times$ ) - 57 days had elapsed between cavity restoration and tooth extraction.
Table 2

Regression analysis between the number of odontoblasts beneath cut dentinal tubules following cavity preparation and restoration factors

\begin{tabular}{ll}
\hline $\begin{array}{l}\text { Mean odontoblast cell numbers } \\
\text { beneath cut dentinal tubules vs: }\end{array}$ & $P$ value \\
\hline Reactionary dentine area & 0.0084 \\
Age of patient & 0.0122 \\
Mean odontoblast cell numbers & 0.167 \\
independent of cut dentinal & \\
tubules & \\
Cavity residual dentine thickness & 0.241 \\
Cavity restoration product & 0.271 \\
Cavity volume & 0.394 \\
Cavity width & 0.510 \\
Premolar position & 0.623 \\
Gender of patient & 0.689 \\
Cavity depth & 0.752 \\
Pulpal inflammatory reaction & 0.756 \\
Cavity walls surface area & 0.825 \\
Cavity floor surface area & 0.901 \\
Time elapsed since surgery & 0.951 \\
\hline
\end{tabular}

$p=0.412)$; time elapsed since cavity restoration (ANOVA $p=0.574$ ); and mandibular or maxillary premolar tooth position (ANOVA $p=0.070$ ).

\subsection{Odontoblast pulpal cell position}

The number of odontoblasts beneath cut dentinal tubules, was found to be not significantly different to the number of odontoblasts independent of the cavity preparation (Table 2). The box chart (Fig. 3) indicated that cavity preparation and restoration, as well as the secretion of reactionary dentine matrix did not irreversibly injure the underlying odontoblast cells.

\subsection{Area of reactionary dentine secreted}

The area of reactionary dentine beneath cut dentinal tubules was found to be related to the odontoblast cell number per unit area (Table 2). The regression graph of this relationship showed that the number of odontoblasts per unit area was reducing, as the area of the reactionary dentine was increasing (Fig. 4). The LRANOVA $p=$ 0.0084 , and the $r^{2}=0.275$; this $r^{2}$ has been claimed to show a fair degree of relationship between the regression variables [32]. This regression relationship between the secretion of reactionary dentine, and a corresponding decrease in odontoblast cell number per unit area, suggests that the secretion of reactionary dentine caused an increase in the length of the pulp dentine border.

\subsection{Age of the patient}

The age of the patient had little effect on the number of odontoblasts per unit area, independent of the cavity preparation (LRANOVA $p=0.216$ ). However, beneath 


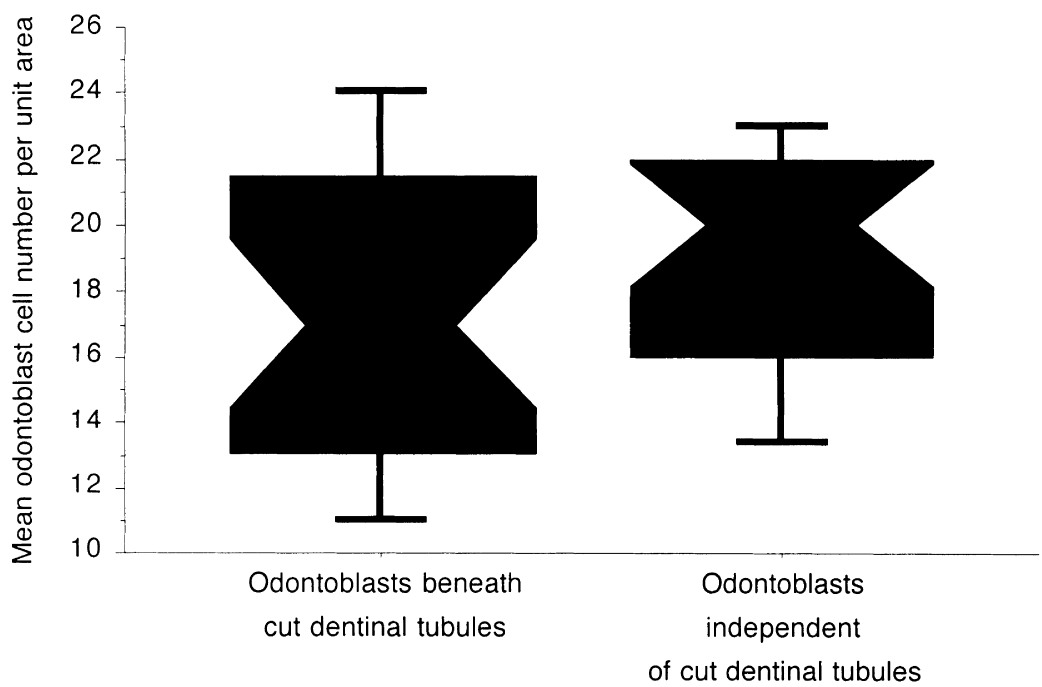

Fig. 3. Bar chart of odontoblast cell numbers per unit of pulp area. The boxes show the standard error of the means, the bars show the standard deviations of the means.

the cavity preparations, the number of odontoblasts was found to decrease per unit area (Table 2) (Fig. 5). The LRANOVA $p=0.0122$; and the $r^{2}=0.286$; this $r^{2}$ has been claimed to show a fair degree of relationship between the regression variables [32]. Furthermore, it was found that the area of reactionary dentine when divided by the odontoblast cell numbers per unit area was found to increase in proportion with the age of the patients (Fig. 6).

The LRANOVA gave $p=0.0013$ and the $r^{2}=0.344$, this $r^{2}$ has been claimed to show a fair degree of relationship between the regression variables [32]. This regression graph indicated that the capacity of each odontoblast to secrete reactionary dentine increased, as the age of the patient increased from 9 years until 17 years of age, irrespective of the cavity preparation or restoration variables.

\subsection{Variables with an insignificant correlation to the number of odontoblasts per unit area}

The following variables were found to have an insignificant correlation with the number of odontoblasts per unit area; time elapsed since surgery; cavity restoration variables such as the floor surface area, depth, volume, width, and residual dentine thickness; pulpal inflammatory reaction; gender of patient; choice of Amalgam/Dycal, IRM or ZOE cavity restoration products and premolar tooth position (Table 2).

\section{Discussion}

This study has demonstrated that the odontoblast cell numbers can be preserved following the careful preparation

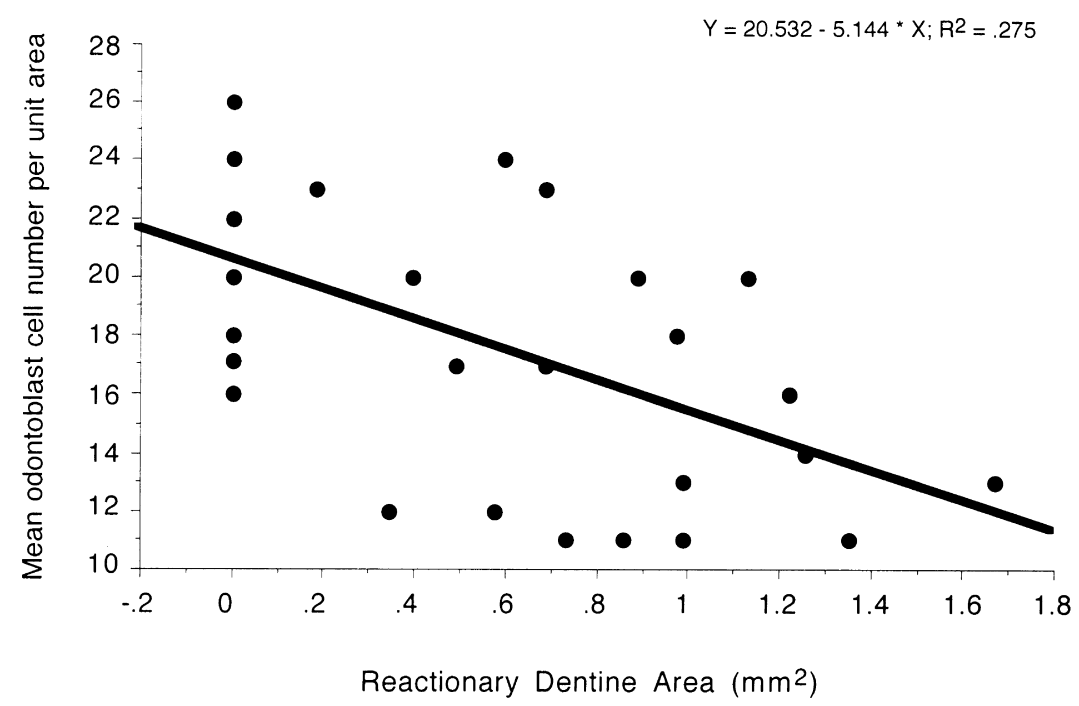

Fig. 4. Regression graph of the mean reactionary dentine area and the number of odontoblasts per unit area, beneath cut dentinal tubules. 


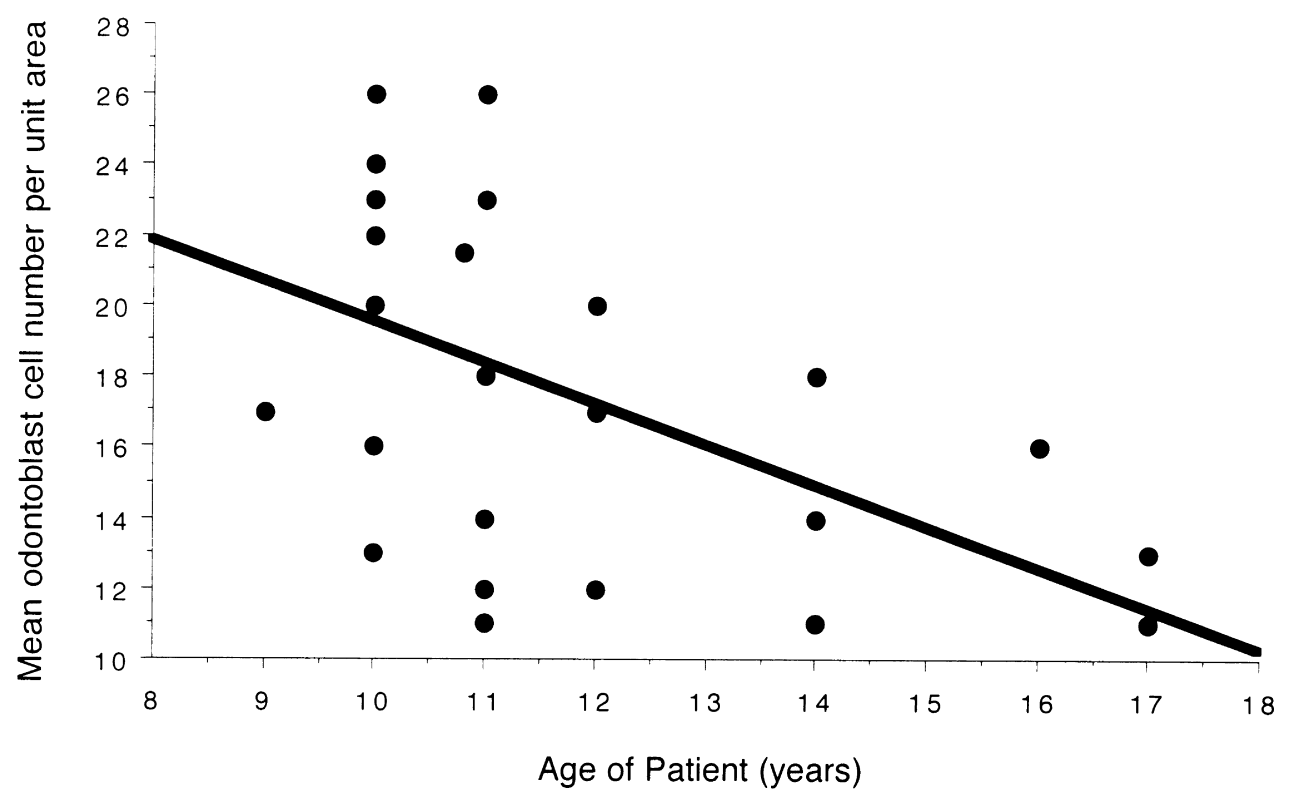

Fig. 5. Regression graph of the age of the patient and odontoblasts per unit area, beneath cut dentinal tubules.

and restoration of dentine cavities. However, cavity preparation and restoration events may injure the pulp, causing necrosis or the activation of apoptosis [34]. The most common method of evaluating pulp tissue reactions to injury is by the qualitative assessment of pulp tissue alterations, however these methods can be subjective [35]. A further problem with these methods, is that although different types of cell death events are easily distinguishable [36], and molecular markers are available for detecting cell death responses [37], human studies can be limited by the need for chronological information on the post-treatment tissue events. In comparison to qualitative approaches to examine pulpal activity, the morphometric analysis of odontoblast cell numbers has proved, in common with previous morphometric studies [29,35] to be able to provide a relatively uncomplicated method for examining a number of variables of interest.

It is not always possible to determine the exact cause of

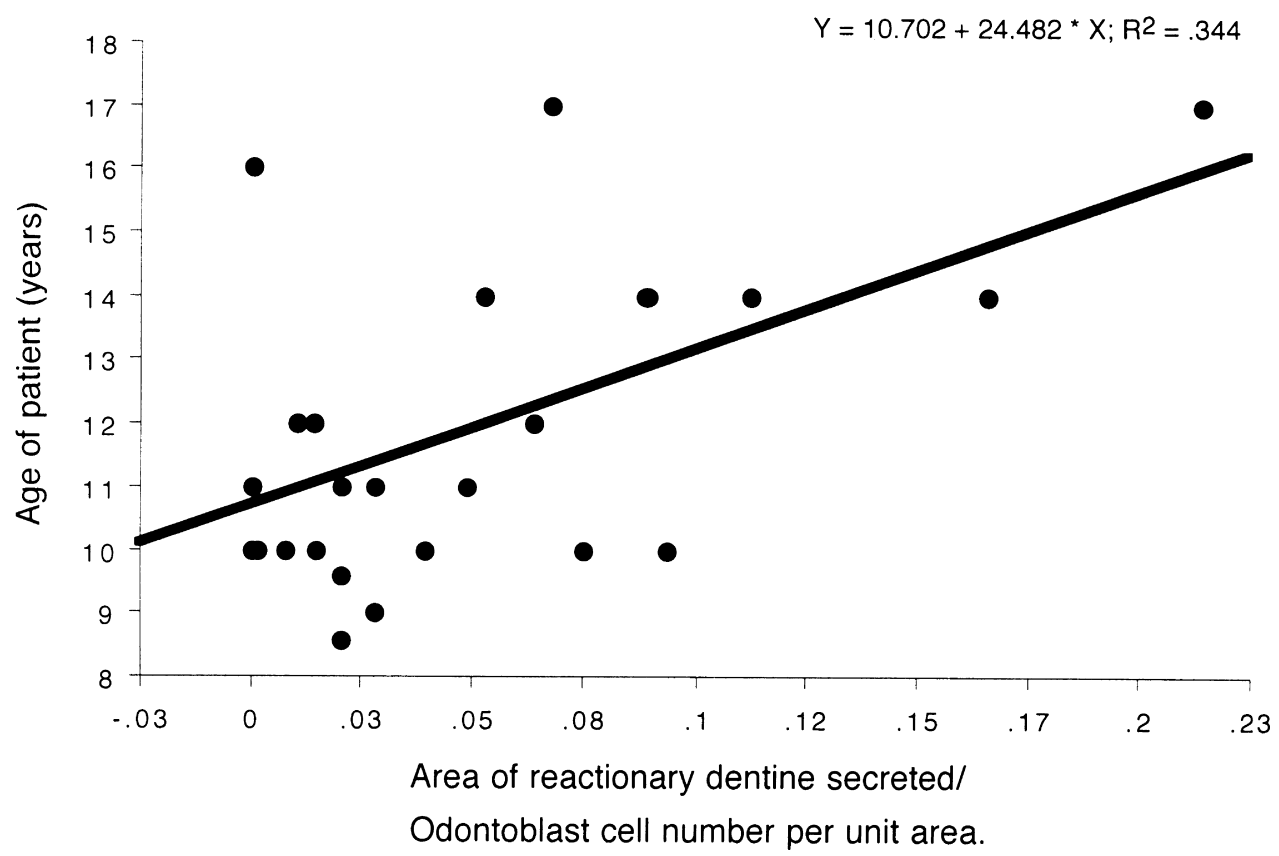

Fig. 6. Regression graph of the age of the patient and area of reactionary dentine matrix/odontoblasts per unit area beneath cut dentinal tubules. 
death when odontoblasts disappear following restorative intervention, since the survival of these cells can be threatened by a variety of injury sources. The main source of injury caused by cavity cutting is claimed to be frictional heat [38]. The amount of intrapulpal heat generated during cavity preparation and restoration is determined by the drill rotation speed [39-42], size, type and shape of the cutting instrument $[43,44]$, length of the time the instrument is in contact with the dentine [45], the amount of pressure exerted on the handpiece $[42,46,47]$, and the use of cooling techniques $[7,48,49]$. In addition to heat, rotary cavity cutting also produces injurious audible and ultrasonic vibrations [50].

Sources of pulpal injury associated with restorative procedures have included conditioning of the dentine cavity wall [51], presence of bacteria [52,53], method of placement of the restorative material [54,55] desiccation [9], pulpal inflammation [56,57], chemical irritants [58] and restoration material toxicity [59], and restoration material temperature $[60,61]$. Odontoblast survival is a multifactorial process, and all of these factors may individually or cumulatively play a role in the demise of odontoblasts. The relative importance of many threats to odontoblast survival during cavity cutting and restoration probably varies from one cavity restoration to another. However, the choice of the restorative material and the parameters of the cut cavity preparation, are among the most controllable and avoidable of the potential sources of injury, and therefore the emphasis of this study has been to focus on these factors.

LRANOVA methods have shown the potential to provide information about the number of odontoblasts per unit area, in response to cavity restoration and patient factor variables. In this present study, little difference was observed between numbers of odontoblasts located beneath cut dentinal tubules, and independent of the cavity preparations (Fig. 3), despite the fact that some secreted a reactionary dentine matrix (Fig. 4). The number of odontoblasts have been reported to fluctuate from birth to 23 years of age, after which they decrease progressively [38] to approximately half their number until 70 years of age is reached [62].

However, graphs of odontoblast cell numbers per unit of pulp area, indicate that odontoblast viability was maintained following the traumatic procedures of cavity preparation and restorative intervention (Figs. 3 and 4). Many studies have reported losses in odontoblast survival, with cavity preparation variables such as a decreasing cavity residual dentine thickness $[22,23,25,26]$. Whilst no such effect was observable in this present study (Table 2), nevertheless, it must be accepted that the cavity residual dentine thickness (RDT) could become more critical as it is reduced, allowing the greater diffusion of potentially injurious cytotoxins in a pulpward direction [63]. Because of the buffering properties of dentine, and the ways in which this can modify the possible cytotoxic properties of dental materials [64] there can be large differences between the effect of a material when it is used to restore exposed and non-exposed cavity preparations. Stanley et al. [65] found that a RDT of $2 \mathrm{~mm}$ would protect the pulp from most restorative procedures, and more recently Pameijer et al. [66] showed that a RDT of $1 \mathrm{~mm}$ or more would be effective at protecting the pulp tissue from the cytotoxic effects of zinc phosphate and glass ionomer cements during luting procedures. The work presented here would suggest that these are cautious estimates, and deeper cavity preparations down to $0.5 \mathrm{~mm}$ appeared to have little effect on odontoblast cell numbers per unit area (Table 2). Furthermore, the restoration of cavity preparations with amalgam/Dycal, IRM or ZOE, did not appear to influence the number of odontoblasts per unit area. This may be attributed to the effect of dentine buffering, which protected the pulp from the possible cytotoxic effect of the restorative products [63].

The quantity of the reactionary dentine secreted by each odontoblast in permanent premolar teeth appeared to increase as the age of the patient increased (Fig. 6). The change in dentinogenic activity of the restored teeth of patients with different ages, can be attributed to maturation related changes within the dental pulp [67-69]. Although the regression graph (Fig. 6) showed that the area of the reactionary dentine secretory activity of each odontoblast increased, this could not be expected to be representative of the tertiary dentinogenic activity of a tooth into old age.

The dentinogenic response potential of teeth could be expected to reach a maturation plateau and thereafter diminish into old age, as a reduction in the rate of dentinogenesis has been observed in the elderly [70,71], and with animal models [72]. Moreover, age has been observed to be a factor in the secretion of reactionary, physiologic sclerotic and reparative dentine [73]. These changes in odontoblast activity can correspond to changes in odontoblasts observed at the molecular level with the ageing process [74]. Changes in dentine due to ageing and disease processes introduce clinically significant alterations in pulpal structure and properties, and our understanding of these alterations is only in its infancy. The impact of these alterations on current and future treatments is expected to be profound [75]. The secretion of reactionary dentine matrix has been observed to be accomplished rapidly and is highly regulated [76], and in this study, reactionary dentine matrix was not uniformly secreted by the odontoblasts in response to cavity restorations. The mechanisms which transduce dentine damage to the odontoblasts and upregulate their synthetic and secretory activity remain incompletely understood [28]. Nevertheless, this study has established that the secretion of reactionary dentine is a more complex process, than an automatic response of the odontoblasts to cavity restoration. The factors which mediate the secretion of reactionary dentine are not known, but they may include the following; the cavity residual dentine thickness $[10,77,78]$, damage to the odontoblast cell process [79], injury to the intratubular elements [80], nerve damage [81-83] and the presence of growth factors [84] solubilised from the dentine matrix $[85,86]$. Despite these investigations, much remains to be 
accomplished in order to understand the mediators of dentinogenesis and the role played by the odontoblast. However, this study has established that carefully cut, deep dentine cavities, do not necessarily irreversibly injure the underlying odontoblast cells. The repair capacity of teeth would appear to be age dependent, this may explain differences in the success of various restorative treatments between patients.

\section{Acknowledgements}

Dr Ross of the University of Birmingham Medical School, for his statistical guidance and independent assessment of the data.

\section{References}

[1] Bránnström M, Lind PO. Pulpal response to early caries. Journal of Dental Research 1965;44:1045-50.

[2] Langeland K. Tissue response to dental caries. Endodontics and Dental Traumatology 1987;3:149-71.

[3] Robertson A, Lundgren T, Andreasen JO, et al. Pulp calcifications in traumatised primary incisors: a morphological and inductive analysis study. European Journal of Oral Science 1997;105:196-206.

[4] Bjørndal L, Darvan T, Thylstrup A. A quantitative light microscopic study of the odontoblast and subodontoblast reactions to active and arrested enamel caries without cavitation. Caries Research 1998;32:59-69.

[5] Bjørndal L, Darvan T. A light microscopic study of odontoblastic and non-odontoblastic cells involved in Tertiary dentinogenesis in welldefined cavitated carious lesions. Caries Research 1999;33:50-60.

[6] Bránnström M. Dental and pulpal response. III. Application of an airstream to exposed dentine: Long observation periods. Acta Odontologica Scandinavia 1960;18:235-52.

[7] Dachi SF, Stigers RW. Pulpal effects of water and air coolants used in high-speed cavity preparations. Journal of the American Dental Association 1968;76:95-8.

[8] Stanley HR. Human pulp response to restorative dental procedures. Gainsville, FL: Storter Printing Co, 1981.

[9] Bránnström M. Communication between the oral cavity and the dental pulp associated with restorative treatment. Operative Dentistry 1984;9:57-68.

[10] Cox CF, White KC, Ramus DL, et al. Reparative dentin: factors affecting its deposition. Quintessence International 1992;23:257-70.

[11] Hunter AR, Treasure ET, Hunter AJ. Increases in cavity volume associated with the removal of class 2 amalgam and composite restorations. Operative Dentistry 1995;20:2-6.

[12] Berg JH. The continuum of restorative materials in paediatric dentistry-a review for the clinician. Paediatric Dentistry 1998;20:93-100.

[13] Linde A. The extracellular matrix of the dental pulp and dentin. Journal of Dental Research 1985;64:523-9.

[14] Linde A, Goldberg M. Dentinogenesis. Critical Reviews in Oral Biology Medicine 1993;4:679-728.

[15] Linde A, Lundgren T. From serum to the mineral phase. The role of the odontoblast in calcium transport and mineral formation. International Journal of Developmental Biology 1995;39:213-22.

[16] Kawasaki K, Tanaka S, Ishikawa T. On the daily incremental lines in human dentine. Archives in Oral Biology 1980;24:939-43.

[17] Stanley HR, Swedlow H. Reaction of the human pulp to cavity preparation; results produced by eight different grinding techniques. Journal of the American Dental Association 1959;58:49-59.
[18] Baume LJ. The biology of pulp and dentin, Monographs in Oral Science. Basel, Switzerland: Karger, 1980. p. 159-82.

[19] Lesot H, Bégue-Kirn C, Kuber MD, et al. Experimental induction of odontoblasts differentiation and stimulation during reparative processes. Cells and Materials 1993;3:201-17.

[20] Smith AJ, Tobias RS, Cassidy N, et al. Odontoblast stimulation in ferrets by dentine matrix components. Archives in Oral Biology 1994;39:13-22.

[21] Stanley HR. Traumatic capacity of high-speed and ultrasonic dental instrumentation. Journal of the American Dental Association 1961;63:750-66.

[22] Stanley HR, Conti AJ, Graham C. Conservation of human research teeth by controlling cavity depth. Oral Surgery 1975;36:151-6.

[23] Darwell BW. Effect of dentine thickness on pulpal changes beneath restorative materials. Australian Dental Journal 1981;26:80-1.

[24] Cox CF. Microleakage related to restorative procedures. Proceedings of the Finnish Dental Society 1992;88(1):83-93.

[25] Santini A, Ivanovic V. The quantitation of tertiary dentin formation in response to materials commonly placed in deep cavities in general practice in the UK. Primary Dental Care 1996;3:14-22.

[26] Lee SJ, Walton RE, Osborne JW. Pulp response to bases and cavity depths. American Journal of Dentistry 1992;5:64-8.

[27] Hilton TJ. Cavity sealers, liners, and bases: Current philosophies and indications for use. Operative Dentistry 1996;21:134-46.

[28] Kardos TB, Hunter AR, Hanlin SM, et al. Odontoblast differentiation; a response to environmental calcium? Endodontics and Dental Traumatology 1998;14:105-11.

[29] Benjamin N, Cleaton-Jones P, Leidal TI. Histometric evaluation of odontoblast responses to Nobetec and Super-Syntrex. Endodontics and Dental Traumatology 1985;1:180-4.

[30] Baume LJ, Fiore-Donno G. Response of the human pulp to a new restorative material. Journal of the American Dental Association 1968;76:1016-22.

[31] Scheffe H. A method for judging all contrasts in the analysis of variance. Biometrika 1953;40:87-104.

[32] Dawson-Saunders B, Trapp RG. Basic and clinical biostatistics. 2nd rev. ed. Connecticut: Appleton \& Lange, 1994. p. 54; p. 125-43.

[33] Mjör IA. Dentin and pulp. Reaction patterns in human teeth. Boca Raton, FL: CRC Press, 1983. p. 63-156.

[34] Vermelin L, Lecolle S, Septier D, et al. Apoptosis in human and rat dental pulp. European Journal of Oral Sciences 1996;104:547-53.

[35] Warfvinge J. Morphometric analysis of teeth with inflamed pulp. Journal of Dental Research 1987;66:78-83.

[36] Ramachandra S, Studzinskj GP. Morphological and biochemical criteria of apoptosis. Cell growth and apoptosis. New York: Oxford University Press, 1995. chap. 7; p. 33.

[37] Takahashi K. Microbiological, pathological, inflammatory, immunological and molecular biological aspects of periradicular disease. International Endodontic Journal 1998;31:311-25.

[38] Zach L. Pulp liability and repair: effect of restorative procedures. Oral Surgery 1972;33:111-21.

[39] Swerdlow H, Stanley HR. Reaction of the human dental pulp to cavity preparation. I. Effect of water spray at $20000 \mathrm{rpm}$. Journal of the American Dental Association 1958;56:317-29.

[40] Croft L, Stanley HR. The effect of a chilled coolant on the human pulp during cavity preparation. Oral Surgery Oral Medicine Oral Pathology 1966;22:66-71.

[41] Diamond RD, Stanley HR, Swerdlow H. Reparative dentin formation resulting from cavity preparation. Journal of Prosthetic Dentistry 1966;16:1127-34.

[42] Hatton JF, Holtzmann DJ, Ferrillo PJ, et al. Effect of handpiece pressure and speed on intrapulpal temperature rise. American Journal of Dental Research 1994;7:108-10.

[43] Ottl P, Lauer H-C. Temperature response in the pulp chamber during ultrahigh-speed tooth preparation with diamond burs of different grit. Journal of Prosthetic Dentistry 1998;80:12-19.

[44] Santini A, Mitchell S. A scanning electron microscopic study of the 
effect of Gluma CPS bonding system on dentinal smear layers produced by different bur types and rotational speeds and on the resin-dentin interface. Quintessence International 1998;29:737-47.

[45] Ohmoto K, Taira M, Shintani H, et al. Studies on dental high-speed cutting with carbide burs used on bovine dentin. Journal of Prosthetic Dentistry 1994;71:319-23.

[46] Liao WM, Taira M, Ohmoto K, et al. Studies on high-speed cutting. Journal of Oral Rehabilitation 1995;22:67-72.

[47] Brisman DL. The effect of speed, pressure, and time on bone temperature during the drilling of implant sites. International Journal of Oral Maxillofacial Implants 1996;11:35-7.

[48] Lloyd BA, Rich JA, Brown WS. Effect of cooling techniques on temperature control and cutting rate for high-speed dental drills. Journal of Dental Research 1978;57:675-84.

[49] Mahon WT, Hembree JH, Yates JL, et al. The influence of ultra speed cutting instruments and coolants on in vitro intrapulpal temperature changes during cavity preparation. Journal of the Tennessee Dental Association 1981;61:13-17.

[50] Holden GP. Some observations on the vibratory phenomena associated with high-speed air turbines and their transmission to living tissue. British Dental Journal 1962;113:265-75.

[51] Tziafas D, Lambrianidis T, Beltes P. Inductive effect of native dentine on the dentinogenic potential of adult dog teeth. Journal of Endodontics 1993;19:116-22.

[52] Bergenholtz G. Effect of bacterial products on inflammatory reactions in the dental pulp. Scandanavian Journal of Dental Research 1977;85:122-9.

[53] Chong BS, Pitt Ford TR, Kariyawasam P. Tissue response to potential root-end filling materials in infected root canals. International Endodontic Journal 1997;30:102-14.

[54] Sigurdsson A, Stancill R, Madison S. Intracanal placement of $\mathrm{Ca}(\mathrm{OH})_{2}$ : a comparison of techniques. Journal of Endodontics 1992;18:367-70.

[55] Kahn FH, Rosenberg PA, Schertzer L, et al. An in vitro evaluation of sealer placement methods. International Endodontics Journal 1997;30:181-6.

[56] Tobias RS, Plant CG, Browne RM. Reduction in pulpal inflammation beneath surface-sealed silicates. International Endodontics Journal 1982;15:173-80.

[57] Sazak S, Günday M, Alatli C. Effect of calcium hydroxide and combinations of ledermix and calcium hydroxide on inflamed pulp in dogs teeth. Journal of Endodontics 1996;22:447-9.

[58] Kawasaki K, Ruben J, Stokroos I, et al. The remineralization of EDTA-treated human dentine. Caries Research 1999;33:275-80.

[59] Kirk EEJ, Meyer MJ. Morphology of the mineralising front and observations of reparative dentine following induction and inhibition of dentinogenesis in the rat incisor. Endodontics and Dental Traumatology 1992;8:195-201.

[60] Stewart G, Bachman T, Hatton J. Temperature rise due to finishing of direct restorative materials. American Journal of Dentistry 1991;4:23-8.

[61] Anil N, Keyf F. Temperature change in the pulp chamber during the application of heat to composite and amalgam cores and its returning time to oral heat. International Dental Journal 1996;46:362-6.

[62] Frohlich E. Alterveranderunngen der pulpa und des paradontiums. Deutsch. Zahnaerztl. Zuch. 1970;25:175-83.

[63] Hamid A, Hume WR. The effect of thickness on diffusion of resin monomers in vitro. Journal of Oral Rehabilitation 1997;24:20-5.

[64] Abou Hashieh I, Franquin JC, Cosset A, et al. Relationship between dentine hydraulic conductance and the cytotoxicity of four dentine bonding resins in vitro. Journal of Dentistry 1998;26:473-7.

[65] Stanley HR. Pulpal response. In: Cohen S, Burns R, editors. Pathways of the pulp, 3rd ed. St Louis, MI: Mosby, 1984.
[66] Pameijer CH, Stanley HR, Ecker G. Biocompatibility of a glass ionomer luting agent. Part II: crown cementation. American Journal of Dentistry 1991;4:134-41.

[67] Takuma S, Nagai N. Ultrastructure of rat odontoblasts in various stages of their development and maturation. Archives in Oral Biology 1971;16:993-1011.

[68] Couve E. Ultrastructural changes during the lifecycle of human odontoblasts. Archives in Oral Biology 1986;31:643-51.

[69] Romagnoli P, Mancini G, Galeotti F, et al. The crown odontoblasts of rat molars from primary dentinogenesis to complete eruption. Journal of Dental Research 1990;69:1857-62.

[70] Morse DR. Age-related changes of the dental pulp complex and their relationship to systemic aging. Oral Surgery Oral Medicine Oral Pathology 1991;72:721-45.

[71] Solheim T. Amount of secondary dentin as an indicator of age. Scandanavian Journal of Dental Research 1992;100:193-9.

[72] Smith AJ, Tobias RS, Plant GC, et al. In vivo morphogenic activity of dentine matrix protein. Journal de Biologie Buccale 1990;18:123-9.

[73] Stanley HR, Pereira JC, Spiegel E, et al. The detection and prevalence of reactive and physiologic dentin, reparative dentin and dead tracts beneath various types of dental lesions according to tooth surface and age. Journal of Pathology 1983;12:257-89.

[74] Moxham BJ, Webb PP, Benjamin M, et al. Changes in the cytoskeleton of cells within the periodontal ligament and dental pulp in the first molar tooth during aging. European Journal of Oral Sciences 1998;106(1):s376-83.

[75] Marshall GW, Marshall SJ, Kinney JH, et al. The dentin substrate: structure and properties related to bonding. Journal of Dentistry 1997;25:441-58.

[76] Smith AJ, Cassidy N, Perry H, et al. Reactionary dentinogenesis. International Journal of Developmental Biology 1995;39:273-80.

[77] Weider SR, Schour I, Mohammed CI. Reparative dentine following cavity and fillings in the rat molar. Oral Surgery Oral Medicine Oral Pathology 1956;9:221-32.

[78] Stanley HR, White CL, McCray L. The rate of tertiary (reparative) dentin formation in the human tooth. Oral Surgery Oral Medicine Oral Pathology 1966;21:180-9.

[79] Tidmarsh BG. Contents of human dentinal tubules. International Endodontics Journal 1981;14:191-6.

[80] Dai X, Ten Cate AR, Limeback H. The extent and distribution of intratubular collagen fibrils in human dentine. Archives in Oral Biology 1991;36:775-8.

[81] Okamura K, Kobayashi I, Matsuo K, et al. An immunohistochemical and ultrastructural study of vasomotor nerves in the microvasculature of human dental pulp. Archives in Oral Biology 1995;40:47-53.

[82] Okamura K, Kobayashi I, Matsuo K, et al. Ultrastructure of the neuromuscular junction of vasomotor nerves in the microvasculature of the human dental pulp. Archives in Oral Biology 1994;39:171-6.

[83] Norlin T, Hilliges M, Brodin L. Immunohistochemical demonstration of exocytosis-regulating proteins with rat molar dentinal tubules. Archives in Oral Biology 1999;44:223-31.

[84] Sloan AJ, Smith AJ. Stimulation of the dentin-pulp complex of rat incisor teeth by transforming growth factor- $\beta$ isoforms $1-3$ in vitro. Archives in Oral Biology 1999;44:149-56.

[85] Finkelman RD, Mohan S, Jennings JC, Taylor AK, Jepsen S, Baylink DJ. Quantitation of growth factors IGF-I SGF/IGF-II and TGF- $\beta$ in human dentine. Journal of Bone Mineralisation Research 1990;5:717-23.

[86] Cassidy N, Fahey M, Prime SS, Smith AJ. Comparative analysis of transforming growth factor-beta isoforms 1-3 in human and rabbit dentine matrices. Archives in Oral Biology 1997;42:219-23. 